\title{
References
}

1. Revulytics-software-piracy-statistics [Електронний ресурс]. - Mode of access : https://www.revulytics.com/blog/2018-revulytics-softwarepiracy-statistics - Title from the screen.

DOI: http://doi.org/10.31617/k.knute.2019-03-19.07

\section{THE ROLE OF ADVERTISEMENTS IN COSMETIC PRODUCTS PROMOTION}

\author{
Marenych V. \\ Candidate of sciences (Ph.D.), Senior Lecturer \\ Department of Journalism and Advertising \\ Kyiv National University of Trade and Economics, Ukraine \\ Koralewski J. \\ coordinator of international relations \\ Academy of Health, Beauty and Education, Poland
}

Keywords: consumer, advertising business, cosmetic products, cosmetics advertising, advertising in the media, art.

Cosmetics advertising is one of the most luxurious, beautiful and breathtaking attention, that is called the high qualities of cosmetic products, which prolong youth and beauty. For a specialist in advertising, creating an advertisement for cosmetics is unlimited possibilities for creating an image, associations with the advertised product. In cosmetics advertising there are no limites by signs: the impossibility of using any images, advertising face, ideas. However, in advertising, work professionals, and they do not allow themselves to make occasional decisions. Using marketing communications, methods for promoting the product, the advertising specialist can creatively approach the advertising of cosmetics, creating for each product its image, individuality.

Recently, advertising for cosmetics often uses celebrities to promote products. This is explained by the fact that the main consumers of cosmetics are women, and for them is very important authority and imitation, however, the advertising of cosmetics for men is also often replete with celebrities of cinema and pop. They associate themselves with celebrities and their lifestyle through the use of cosmetics and fragrances (perfumes). Advertising, which promotes cosmetics by the stars of cinema and show business, suggests that this or that product is offered for «star advice» that he uses in life. It's like a secret or a way to achieve success in life, a relationship between your lifestyle and the style of life of a star. But this does not mean that all stars promoting 
cosmetics use advertised goods in their lives. For many, it's just a job, just roles, contracts, money. People by nature tend to trust advertising. When it comes to advertising for cosmetics, almost $70 \%$ of girls and women who use cosmetics say that they buy it guided by advertising. That is why the manufacturers of cosmetics for advertising are very serious. It's important that advertising does not disappoint the consumer, but on the other hand, more and more have regular customers.

The word cosmetics came from Greece, which means - «the doctrine of the means and methods of improving the appearance of a human being.» Cosmetics are also referred to as means and methods of skin care, hair and nails used to improve the appearance of the person, as well as substances that add freshness and beauty to the face and body [1].

Very often, cosmetics ads can be found on pages of glossy magazines, the pages of which are filled with advertising of cosmetic products involving models: women and men. Consider the features of advertising in the press, in glossy magazines, its advantages and disadvantages, as well as the audience, which is targeted by advertising in the press. Printed ads appeared a bit earlier than all other types of advertising and are one of the easiest ways to convey product information to the consumer. From the moment of its appearance came out a lot of varieties of print ads.

The most commonly used print ads are newspaper and magazine ads. Their large press run provides a low cost per promotional contact. The duration of the impact of a newspaper ad is about one to two days, a magazine - from one week to one or two months (but this term can be much longer if the magazine is, for example, in the hall of beauty or hotel).

Glossy magazines occupy a special place as they shape the lifestyle of their readers, including the need for products. Initially, glossy magazines were predominantly feminine, but now they are also issued for men, children and specialized. For example, in a women's magazine devoted to women's issues: a fashion, self-care about the skin of the face, body, hair. In this magazine, where articles are published on the subject data, various tips and comments are given. Advertising should be addressed to one or another audience, otherwise it will be useless. The effectiveness of advertising in specialized magazines is higher due to more accurate positioning [2].

In a special group of glossy magazines you can select so-called lifestyle magazines. They have no clear direction, but they promote a certain way of life. Basically these magazines say about modern trends in the luxury world to one degree or another. The most authoritative of them are able to write about fashion, about luxury as about certain aspects of cultural life, revealing the philosophy of style, telling about fashion brands, and their significance in life. In addition, the magazine includes articles on psychology, and those relating to legal issues. The main character of any «gloss» is always Fashion. 
It can change - capricious, stellar - only the interest of consumers to it always remains unchanged.

Advertising of low price cosmetics can often be seen in inexpensive magazines, such as «Lisa» or «Magic and beauty».

Mass market cosmetics are cosmetic products intended for the mass consumer. Typically, these cosmetics are used to care for the skin, hair and nails. Representatives of such cosmetics are the brands Nivea, Garnier. Advertising of cosmetics of this class can be seen in expensive glossy magazines, and in cheaper ones.

Thus, in today's world, advertising is a priority in the field of cosmetic sales. Promotion of goods and development of cosmetic business will be more successful if the company develops and implements effective advertising projects. In the face of fierce competition, advertising is of great importance as a means of bringing information about the product to the mass consumer. Taking into account the competitive nature of cosmetic products in the market of supply and demand, the role of factors of promotion and positioning is significantly increasing.

\title{
References
}

1. Istoriya vynyknennya kosmetyky [Elektronnyy resurs]. - Rezhym dostupu : http://mestectvo.com/zvnovost/438-istkosmet.html

2. Reklama kosmetyky $\mathrm{v}$ hlyantsevykh zhurnalakh za uchastyu zirok kino $\mathrm{i}$ shou-biznesu [Elektronnyy resurs]. - Rezhym dostupu : https:// ukrbukva.net/69392-Reklama-kosmetiki-v-glyancevyh-zhurnalah-suchastiem-zviezd-kino-i-shou-biznesa.html

DOI: http://doi.org/10.31617/k.knute.2019-03-19.08 REASONS AND EFFECTS OF ONLINE AD BLOCKING

\author{
Moroz M. \\ Dr. hab., prof. \\ Department of Organization and Economics \\ Wrocław University of Economics, Poland \\ Hlynskyy N. \\ Candidate of sciences (Ph.D.), \\ Associate Professor \\ Department of Marketing and Logistics \\ Lviv Polytechnic National University, Ukraine
}

Keywords: online-advertising, blocking, marketing, Internet users. 